\title{
Akuntansi potali: membangun praktik akuntansi penjualan di pasar tradisional (studi etnometodologi islam)
}

\author{
Mohamad Anwar Thalib ${ }^{1}$, Supandi Rahman ${ }^{1}$, Mei K. Abdullah ${ }^{1}$, Yulia Puspitasari Gobel ${ }^{1}$ \\ ${ }^{1}$ Institut Agama Islam Negeri Sultan Amai Gorontalo, Jl. Sultan Amai, Gorontalo, Indonesia
}

\author{
Diterima: 25 Juni 2020 \\ Direvisi: 11 September \\ 2020 \\ Disetujui: 5 Oktober \\ 2020 \\ Korespondensi: \\ Mohammad Anwar Thalib \\ mat@iaingorontalo.ac.id
}

DOI:

http://dx.doi.org/10.17977/ um004v8i12021p25

\begin{abstract}
This study aims to construct the efforts of traders to conduct sales accounting practices in traditional market Gorontalo. Research in sales accounting based on local wisdom is important to maintain the accounting sustainability in Indonesia. Islamic ethnomethodology is the approach used in this research. There are 5 stages of data analysis comprising of: amal, ilmu, iman, informasi wahyu, and ihsan (amiiin). The research finds two ways of selling accounting practices which are bargaining and giving bonus cake. These methods are driven by the spirits of Gorontalo Islamic culture, patience, persistence, and brotherhood. The spirits exist because the sellers have demand on income that represents blessing from God. The findings of this research are important because the existence of sales accounting based on Gorontalo's cultural values have been successfully explored and proven.

Keywords: Sales Accounting; Gorontalo Culture; Traditional Market; Islamic Etnomethodology

Abstrak

Penelitian ini bertujuan untuk merumuskan cara pedagang di pasar tradisional Gorontalo mempraktikkan akuntansi penjualan. Penelitian akuntansi penjualan berbasis kearifan lokal penting untuk dilakukan sebagai upaya untuk menjaga kelangsungan akuntansi di Indonesia. Etnometodologi Islam adalah pendekatan yang digunakan dalam riset ini. Terdapat 5 tahap analisis data yaitu: amal, ilmu, iman, informasi wahyu, dan ihsan (amiiin). Hasil penelitian menemukan dua cara praktik akuntansi penjualan yaitu: tawar menawar dan memberikan bonus kue. Kedua cara tersebut digerakkan oleh semangat budaya Islam Gorontalo berupa kesabaran, kegigihan, dan persaudaraan. Semangat tersebut hidup karena para penjual ingin mendapatkan rejeki yang merupakan berkah dari Tuhan. Temuan riset ini penting karena berhasil menggali serta menunjukkan keberadaan akuntansi penjualan berbasis nilai budaya Gorontalo. Kata kunci: Akuntansi Penjualan; Budaya Gorontalo; Etnometodologi Islam; Pasar Tradisional
\end{abstract}

\section{PENDAHULUAN}

Riset ini dilakukan karena adanya keistimewaan atau keunikan aktivitas penjualan di pasar tradisional Gorontalo. Keunikan pertama adalah barang yang dijual oleh para penjual pada umumnya merupakan hasil alam daerah setempat sehingga harga produk di pasar tradisional cenderung lebih bersahabat dibandingkan dengan pasar modern. Keunikan kedua berhubungan dengan adanya proses tawar menawar barang yang menghidupkan kedekatan interaksi diantara sesama. Keunikan ketiga terkait dengan iman yang direpresentasikan melalui tindakan para penjual yang membagikan barang dagang secara gratis kepada orang yang membutuhkan. Keimanan itu digerakkan oleh rasa syukur atas rejeki yang telah diperoleh dari Tuhan. Pada dasarnya, proses penjualan yang hidup dengan semangat kebersamaan, tolong menolong, dan iman kepada Tuhan merupakan cerminan dari nilai kearifan lokal masyarakat setempat. Nilai itu berupa adati hula- hula'a to syara'a, syara'a hula-hula'a to quru'ani, syara' bersendi Alquran (Daulima \& Eraku, 2009; Mashadi, 2012). Adat yang didasarkan pada nilai-nilai Islam adalah ciri khas kebudayaan masyarakat Gorontalo. Kondisi menarik ditunjukkan dengan nilai budaya Islam yang diterapkan tidak hanya di ritual adat namun juga terinternalisasi di setiap aktivitas masyarakat setempat (termasuk berdagang). Keunikan nilai budaya ini yang menjadikan pasar tradisional di Gorontalo memiliki ciri khas tersendiri.

Selanjutnya, penjualan dalam keilmuan akuntansi modern diatur dalam PSAK No 23. Standar tersebut menjelaskan beberapa sumber pendapatan yaitu penjualan, penghasilan jasa, deviden, royalti, dan sewa. Penjualan merupakan sebutan berbeda dari pendapatan yang diperoleh melalui 
penjualan barang (Ikatan Akuntan Indonesia, 2015). Dengan kata lain, akuntansi penjualan merupakan pendapatan yang diperoleh melalui penjualan barang. Namun sebelum mengakui sebagai pendapatan penjualan, terdapat 5 syarat yang harus dipenuhi (PSAK No. 23). Dalam akuntansi modern, konsep penjualan tersebut hidup dengan nilai-nilai modernitas berupa matrealistik, utilitarian, dan egoistik (Kamayanti \& Ahmar, 2019; Musdalifa \& Mulawarman, 2019; Triyuwono, 2011b, 2015; Wiyarni et al., 2013). Nilai tersebut tercermin melalui konsep penjualan yang terbatas pada dimensi materi (uang), pengakuan penjualan yang berfokus pada hasil serta mengabaikan proses untuk memperoleh penjualan (nilai utilitarian) yang mengakibatkan sebagian besar hasil penjualan diperuntukkan untuk para pemegang saham, manajer, dan penguasa lain (nilai egoistik).

Sementara itu, jika dilihat dari sudut pandang Islam sebagai basis budaya dan juga praktik perdagangan di pasar tradisional Gorontalo, penjualan bukan untuk menghitung, menumpuk, hingga menikmati materi demi kepentingan pribadi. Dalam Islam, Tuhan menciptakan manusia dengan kemampuan akal untuk berpikir dan hati untuk merasa. Rasa tersebut turut berperan dalam segala aktivitas manusia termasuk berjualan, misalnya kebahagiaan ketika barang dagangan bisa bermanfaat untuk pembeli, kebersamaan di dalam proses tawar menawar barang, serta perasaan syukur dan saling berbagi atas rejeki yang diberikan oleh Tuhan. Dengan kata lain, penjualan tidak hanya nominal pendapatan yang jumlah penjualan bisa dihitung dengan akal, tetapi terdapat juga terdapat nilai non-materi berupa rasa dan iman yang dapat dipahami oleh hati. Kedua hal itu mengarahkan penjualan bukan untuk mendapatkan angka pendapatan yang tinggi, namun penjualan juga perlu mempertimbangkan aturan agama dalam proses memperoleh pendapatan. Kondisi tersebut terjadi karena tujuan segala aktivitas manusia di muka bumi (termasuk aktivitas memperoleh pendapatan dari penjualan) adalah untuk beribadah kepada Tuhan.

Sehubungan dengan itu, tujuan penelitian ini adalah untuk melakukan eksplorasi proses dalam perolehan pendapatan dari aktivitas penjualan yang terkait dengan nilai-nilai non-materi berupa kearifan lokal dan religiusitas. Selanjutnya, tema penelitian ini penting dikaji karena untuk menjaga kelangsungan praktik akuntansi penjualan berbasis nilai-nilai kedaerahan dan religiusitas. Mathews \& Perera (1993) menjelaskan bahwa akuntansi bukan saja produk dari lingkungan namun akuntansi juga dapat membentuk lingkungan. Hal tersebut berarti setiap lingkungan memiliki versi akuntansi yang dipraktikkan sesuai dengan sistem dan nilai kepercayaan. Pengadopsian akuntansi yang bukan berasal dari lingkungan tersebut dapat mengubah perilaku masyarakat sejalan dengan nilai-nilai dari lingkungan akuntansi itu berasal (Kamayanti \& Ahmar, 2019; Triyuwono, 2011b). Dengan demikian, implementasi akuntansi yang dibawa dari dunia lain (barat) dapat memudarkan bahkan menghilangkan akuntansi lokal yang terkait dengan rasa kebersamaan, saling berbagi, bahkan rasa syukur kepada Tuhan.

Riset akuntansi dalam ruang lingkup pasar tradisional yang berhubungan dengan nilai-nilai kearifan lokal telah dilakukan oleh beberapa peneliti. Wiyarni et al. (2013) menemukan bahwa para pedagang di pasar tradisional Jawa memegang nilai toleransi ketika melakukan transaksi. Nilai toleransi tersebut digambarkan melalui tindakan para pedagang yang menghormati serta menghargai keputusan pembeli atau sesama penjual. Para pedagang menghargai tindakan pembeli yang jika pembeli tidak memilih barang yang telah disepakati, maka pembeli beralih ke supplier yang terletak di dekat lokasi pedagang tersebut. Nilai toleransi tersebut merupakan gambaran pengimplementasian kalimat bijak berupa "Tata Tentrem Kerta Raharja" yang berarti mengajak setiap orang untuk mewujudkan keinginan secara tertib tanpa menyebabkan kekacauan dan tanpa menciptakan sesuatu yang dapat membuat situasi menjadi tidak harmonis. Selanjutnya, Thalib (2019b) menemukan fakta dimana sistem barter dan pengurangan jumlah produksi di musim buah merupakan cara yang digunakan oleh pedagang untuk menghindari kerugian. Tindakan tersebut merupakan cerminan dari kalimat bijak "mopo'o tanggalo duhelo (penuh kesabaran)". Meskipun riset mengenai akuntansi di area pasar tradisional telah dilakukan oleh beberapa peneliti, namun riset tersebut belum menguraikan secara spesifik cara pedagang memperoleh pendapatan penjualan yang berhubungan dengan nilai budaya lokal Gorontalo. Oleh sebab itu, berdasarkan pembahasan di atas yang terkait dengan keistimewaan, urgensi, hingga hasil riset sebelumnya, maka penelitian ini dilakukan untuk mendapatkan informasi secara lengkat terkait dengan praktik akuntansi penjualan di pasar tradisional Gorontalo. Pertanyaan penelitian ini berhubungan dengan bagaimana cara pedagang di pasar tradisional Gorontalo mempraktikkan akuntansi penjualan. Sehubungan dengan itu, maka tujuan penelitian adalah untuk merumuskan cara pedagang di pasar tradisional Gorontalo dalam mempraktikkan akuntansi penjualan. Kontribusi teori dari penelitian ini adalah memberikan referensi akuntansi penjualan berbasis nilai-nilai budaya Islam di Gorontalo. Sementara itu, kontribusi praktik adalah untuk menjaga kelangsungan akuntansi penjualan berbasis nilai-nilai budaya lokal Gorontalo. 


\section{METODE}

Penelitian ini menggunakan paradigma spiritual (Islam) sebagai sudut pandang dalam melihat realitas akuntansi penjualan. Perspektif tersebut dipilih karena tujuan penelitian ini sesuai dengan asumsi dasar yang dimiliki. Asumsi dasar pertama adalah ontology dimana paradigma Islam meyakini bahwa Tuhan merupakan satu-satunya pencipta realitas yang ada bahkan yang benar-benar realitas adalah Tuhan itu sendiri (Kamayanti, 2015, 2016b, 2016a; Mulawarman, 2010, 2013; Triyuwono, 2011a, 2015). Pada hakikatnya, Tuhan merupakan realitas yang bertajjali dalam bentuk fisik, psikis, spiritual, dan sifat. Dengan kata lain, realitas yang ada tidak saja terdiri dari fisik (materi) namun juga terdapat non-materi, serta realitas tersebut merupakan pancaran dan ciptaan dari Tuhan (Triyuwono, 2013). Kebenaran yang diakui oleh paradigma Islam sesuai dengan realitas yang ingin ditelusuri dalam penelitian ini yaitu praktik akuntansi penjualan yang terdiri dari materi dan non-materi serta diyakini bahwa praktik itu adalah ciptaan Tuhan.

Lebih lanjut, asumsi dasar yang kedua adalah epistemology. Dalam membangun ilmu pengetahuan, paradigma ini tidak saja menggunakan akal dan intuisi, tetapi terdapat juga wahyu yang berperan dalam menuntun akal dan intuisi. Ilmu dapat diperoleh melalui akal, intuisi, pengalaman, tradisi, dan juga spekulasi teoretis. Namun menariknya, berbagai macam sumber pengetahuan tersebut dibingkai dalam nilai-nilai wahyu al-Quran (Sardar, 1985). Dengan kata lain, wahyu adalah pusat dari segala sumber ilmu pengetahuan. Hal ini yang mengarahkan penelitian ini untuk memilih paradigma Islam sebagai sudut pandang penelitian karena masyarakat Gorontalo menerapkan hal yang serupa, yaitu menjadikan nilai-nilai Islam sebagai basis aktivitas kehidupan (termasuk memperaktikkan akuntansi penjualan). Hal ini tercermin melalui filosofi budaya (Daulima \& Eraku, 2009). Selanjutnya, asumsi dasar ketiga adalah tujuan penelitian dimana paradigma Islam menghendaki bahwa tujuan dari penelitian adalah untuk membangkitkan kesadaran ketuhanan. Kesadaran dapat terbentuk ketika informasi dari hasil penelitian akuntansi terdiri dari materi, mental, dan spiritual (Triyuwono, 2013). Asumsi tersebut sejalan dengan tujuan dari penelitian ini yaitu membentuk praktik akuntansi penjualan yang terdiri dari materi, mental, serta syarat dengan nilai-nilai lokal hingga religiusitas. Selanjutnya, etnometodologi Islam dipilih sebagai pendekatan penelitian. Hal ini disebabkan karena keselarasan antara asumsi dasar etnometodologi Islam dengan tujuan penelitian. Garfinkel, (1967) menyebutkan "Ethnomethodological studies analyze everyday activities as members' methods for making those . same activities visibly-rational-and-reportable-forall-practical-purposes, i.e., "accountable," as organizations of commonplace everyday activities". Selanjutnya, Thalib (2017, 2019a, 2019b) menjelaskan "Etnometodologi Islam adalah metode yang digunakan untuk mempelajari cara hidup anggota kelompok, melalui analisis amal, ilmu, iman, informasi wahyu, dan ihsan (amiiin), membawa akhir dari setiap temuan kepada Sang Pencipta (kesadaran ketuhanan)" (Thalib, 2017, 2019a, 2019b).

Pada umumnya, etnometodologi modern dan Islam adalah sebuah pendekatan yang berusaha mempelajari cara hidup anggota kelompok. Namun etnometodologi modern adalah metode yang berada pada ranah paradigma interpretif (Garfinkel, 1967; Kamayanti, 2016b; Mulawarman, 2010, 2013; Thalib, 2017; Triyuwono, 2011a, 2013). Thalib $(2017,2019)$ menyebutkan bahwa etnometodologi Islam berada di ranah paradigma Islam. Oleh sebab itu, meskipun tujuan kedua metode adalah untuk mempelajari cara hidup anggota kelompok, namun masing-masing memiliki asumsi dasar yang berbeda. Etnometodologi modern mengakui bahwa cara hidup anggota kelompok merupakan produk yang diciptakan oleh anggota kelompok itu sendiri (Garfinkel, 1967; Kamayanti, 2016b; Thalib, 2017), sedangkan etnometdologi Islam mengakui bahwa hakikatnya cara hidup anggota kelompok merupakan ciptaan dari Tuhan Yang Maha Esa (Thalib, 2017, 2019a, 2019b). Selanjutnya, secara epistemologi, etnometodologi modern tidak memberikan ruang adanya wahyu dalam pencarian ilmu pengetahuan (Garfinkel, 1967; Kamayanti, 2016b; Thalib, 2017). Sebaliknya, etnometodologi Islam adalah metode yang meletakan wahyu sebagai salah satu sumber pencarian ilmu pengetahuan, bahkan wahyu menjadi pusat dari segala sumber pengetahuan (Thalib, 2017). Sementara itu, tujuan dari etnometodologi modern sebatas pada memahami realitas yang ada (Garfinkel, 1967; Kamayanti, 2016b; Mulawarman, 2010, 2013; Thalib, 2017; Triyuwono, 2011a, 2013), sedangkan etnometodologi Islam bertujuan untuk membangkitkan kesadaran ketuhanan (Thalib, 2017).

Lebih lanjut, penelitian ini menggunakan alat analisis dari etnometodologi Islam yaitu amiiin karena alat analisis ini secara khusus dibentuk untuk menggali serta merumuskan cara hidup anggota kelompok yang terdiri dari materi, mental, spiritual, yang direlasikan dengan firman Tuhan (Thalib, 2017, 2019b, 2019a). Tahapan analisis data pertama adalah amal. Amal merupakan segala bentuk ungkapan baik itu bahasa/ekspresi/tindakan yang menunjukkan cara pedagang di pasar tradisional mempraktikkan akuntansi penjualan. Potensi diri yang digunakan untuk menemukan cara tersebut adalah pancaindera (Thalib, 2017, 2019b, 2019a). Pengamatan partisipan serta wawancara adalah 
metode yang digunakan oleh peneliti untuk mengumpulkan data. Pengamatan partisipan adalah menyaksikan dan membuat catatan lapangan dari kejauhan. Perekaman data dilakukan tanpa terlibat langsung dengan aktivitas masyarakat (Burhan, 2012; Creswell et al., 2015; Moleong, 2015; Sugiyono, 2014). Jenis wawancara yang digunakan adalah wawancara terstruktur dan tidak terstruktur. Wawancara terstruktur yaitu perumusan pertanyaan penelitian dilakukan terlebih dahulu. Sebaliknya, pertanyaan tidak terstruktur biasanya tidak disusun terlebih dahulu, dimana tanya jawab berlangsung seperti dalam percakapan sehari-hari (Burhan, 2012; Creswell et al., 2015; Moleong, 2015; Sugiyono, 2014). Hal tersebut berarti pertanyaan sesuai tujuan penelitian disusun terlebih dahulu dalam penelitian ini kemudian pertanyaan dikembangkan pada proses wawancara dengan informan. Tahapan kedua adalah analisis ilmu. Ilmu disini berarti makna rasionalitas dari amal dimana makna tersebut merupakan pemahaman antara sesama anggota kelompok yang berlaku dalam konteks ruang dan waktu. Pada tahap ini, penelitian menggunakan potensi diri berupa akal untuk menemukan makna rasional (Thalib, 2017, 2019b, 2019a). Tahapan ilmu mirip dengan analisis refleksifitas pada etnometodologi modern, yaitu makna yang dipahami oleh sesama anggota kelompok (Garfinkel, 1967; Kamayanti, 2016b; Thalib, 2017). Namun, ilmu dalam etnometodologi Islam adalah pemahaman antara sesama anggota kelompok yang pada hakikatnya diciptakan oleh Tuhan. Sebaliknya, refleksifitas dalam etnometodologi modern merupakan makna yang diciptakan oleh sesama anggota kelompok (Garfinkel, 1967; Kamayanti, 2016b; Thalib, 2017).

Tahap ketiga adalah analisis iman yang merupakan nilai-nilai non-materi yang menggerakkan cara pedagang di pasar tradisional dalam praktik akuntansi penjualan. Penelitian ini menggunakan potensi diri berupa intuisi untuk menemukan nilai-nilai non-materi tersebut (Thalib, 2017, 2019b, 2019a). Purwanto (2007) menjelaskan bahwa intuisi merupakan salah satu potensi diri yang diberikan oleh Tuhan kepada manusia untuk bisa merasakan dan juga menangkap isyarat dari Tuhan. Upaya untuk menghadirkan nilai-nilai non-materi terkait dengan mental dan spiritual merupakan konsekuensi yang logis dari paradigma Islam, sebab asumsi realitas dalam paradigma ini mencakup materi, mental, spiritual, hingga sifat (Purwanto, 2007; Triyuwono, 2011a, 2015, 2013). Tahap analisis keempat adalah informasi wahyu. Tahapan ini berfungsi untuk merelasikan temuan dengan informasi wahyu (Thalib, 2017, 2019b, 2019a). Sebagaimana yang dijelaskan oleh Sardar (1985), wahyu merupakan salah satu sumber pengetahuan dalam paradigma Islah, bahkan segala pengetahuan yang diperoleh harus berada dalam bingkai nilai-nilai Al-Quran dan hadist. Tahap terakhir (kelima) adalah analisis ihsan yang merupakan hikmah dibalik penciptaan Tuhan (Thalib, 2017, 2019b, 2019a).

Selanjutnya, lokasi penelitian ini berada di pasar Kamis Tapa, Desa Talumopatu, Kecamatan Tapa, Kabupaten Bone Bolango, Provinsi Gorontalo. Lokasi ini dipilih berdasarkan pada 3 alasan. Alasan pertama yaitu masyarakat setempat (yang juga merupakan pedagang di pasar kamis Tapa) masih memegang kuat nilai-nilai kebudayaan. Alasan kedua berhubungan dengan lokasi yang mudah diakses untuk penelitian. Alasan ketiga terkait dengan hubungan baik antara peneliti dengan bebearapa penjual di tempat tersebut sehingga memudahkan proses untuk mendapatkan informan penelitian. Lebih lanjut, informan penelitian ini berjumlah tiga orang yaitu ta Meri, ta Tini, dan ta Nou. Ketiga informan dipilih berdasarkan tiga alasan. Alasan pertama karena para informan adalah pedagang yang telah menjual produk lebih dari 10 tahun dan sampai penelitian dilkukan belum pernah berdagang di pasar tradisonal lain. Alasan kedua adalah informan tersebut bersedia untuk meluangkan waktu serta berbagi cerita pengalaman kepada peneliti. Alasan ketiga karena para informan menjual jenis dagangan yang sama yaitu kue dan gorengan. Kemiripan jenis dagangan itu memudahkan penelitian ini untuk memahami dan memaknai cara pedagang mempraktikkan akuntansi penjualan.

\section{HASIL DAN PEMBAHASAN}

\section{Kesabaran dan Kegigihan dalam Aktivitas Tawar Menawar}

Penjualan sering disebut oleh masyarakat Gorontalo dengan potali yang merupakan aktivitas dengan tujuan untuk memperoleh rejeki. Kegiatan potali di pasar Kamis juga sama dengan pasar tradisional lainnya yang identik dengan proses tawar menawar. Berikut merupakan cuplikan wawancara ta Meri mengenai hal tersebut:

"Berjualan (kue) ini kasihan sama dengan berjualan rempah-rempah ini. Kalau rempahrempah mereka bilang sepuluh ribu tomat. Ditambah ya, dibuat panas itu timbangannya. Tambah ya, satu ons, padahal sudah disitulah keuntungan kami kasihan. Kami itu seperti berjualan tomat diambil per tas. Kalau misalnya tujuh puluh atau berapa, tergantung. pasaran juga rempah-rempah. Kalau cabai sekarang mahal kan”. 
Penuturan tersebut merupakan potongan wawancara ta Meri. Sehubungan dengan pernyataan tersebut, dapat diketahui bahwa berjualan kue mirip dengan berjualan rempah-rempah. Pembeli selalu meminta agar berat timbangan barang yang dibeli untuk ditambah. Namun permintaan untuk menambah berat timbangan itu bisa saja menghilangkan keuntungan dari penjual. Keadaan penjual khususnya ta Meri akan semakin memprihatinkan jika kondisi itu dihadapkan juga dengan kenaikan harga kebutuhan pokok. Berdasarkan pada pada penjelasan ta Meri sebelumnya, ditemukan cara praktik akuntansi penjualan berupa kegiatan tawar menawar. Cara ini terdapat pada amal "ditambah ya, dibuat panas itu timbangannya". Ilmu dari amal ini adalah para pembeli berusaha melakukan kompromi dengan penjual agar diberikan tambahan barang. Namun terkadang tambahan itu mendekati harga pokok dari produk yang dijual. Pemberian tambahan kepada penjual tersebut mengakibatkan penjual tidak mendapatkan keuntungan dari kegiatan usaha. Selanjutnya, ta Meri kembali menuturkan bahwa:

“Tambah sedikit ya. Terlebih lagi kalau perempuan yang berbelanja, kalau laki-laki paling kalau sudah diimbangan kasian, sudah tidak lagi berkomentar. Adakalanya ditimbangkan sudah setengah kilo, "ditambah dua biji ya”. Iya, jadi misalnya kami yang berjualan itu, kalau marah tapi satu kampung, lain kali mereka tidak membeli lagi".

Penuturan ta Meri sebelumnya menunjukkan bahwa terdapat perbedaan cara perempuan dan laki-laki ketika berbelanja. Pembeli laki-laki tidak lagi meminta agar diberikan tambahan dari apa yang dibeli. Kondisi tersebut berbeda dengan pembeli perempuan, walaupun ukuran yang dibeli telah sama dengan apa yang diberikan oleh penjual, namun pembeli perempuan akan tetap meminta agar penjual memberikan tambahan. Tindakan yang dilakukan oleh ta Meri adalah mengikuti permintaan dari pembeli. Hal ini disebabkan oleh 2 faktor. Faktor pertama karena sejumlah besar pembeli adalah warga sekitar sehingga ada perasaan sungkan untuk menolak permintaan. Alasan kedua agar tidak kehilangan pelanggan. Pada penuturan ta Meri, ditemukan praktik akuntansi penjualan berupa kegiatan tawar menawar. Praktik ini terdapat pada amal "terlebih lagi kalau perempuan yang. berbelanja, kalau laki-laki paling kalau sudah ditimbangan kasian, sudah tidak lagi berkomentar". Ilmu dari amal ini adalah terdapat perbedaan cara laki-laki dan perempuan membeli di pasar Kamis dimana pembeli laki-laki tidak melakukan kompromi harga dengan penjual. Ketika penjual telah memberikan jumlah barang sebagaimana yang dibeli, maka pembeli pria tidak akan menawar lagi. Kondisi berbeda jika dengan pembeli perempuan, meskipun penjual telah memberikan jumlah barang sesuai dengan apa yang dibayar, namun pembeli perempuan tetap meminta agar penjual melebihkan jumlah barang tersebut.

Praktik tawar menawar di atas merupakan tindakan yang telah menjadi kebiasaan di pasar tradisional. Tindakan ini dengan sendirinya membangun pemahaman bersama diantara sesama anggota. Sebagaimana yang dikemukakan pada analisis ilmu bahwa pemahaman bersama tersebut berupa pembeli dapat melakukan kompromi harga atas barang yang dijual oleh para pedagang. Apabila antara pembeli dan penjual telah menyepakati harga barang maka transaksi jual beli akan terjadi, begitu pula sebaliknya. Selanjutnya, berdasarkan sikap para pedagang yang tetap melayani pembeli yang melakukan kompromi terhadap harga barang, serta keputusan pedagang untuk tidak berdiam diri (tetap berjualan di pasar tradisional), meskipun keuntungan yang didapatkan berkurang akibat praktik tawar menawar, hal tersebut menunjukkan bahwa terdapat semangat (iman) kesabaran dan kegigihan penjual pada aktivitas tersebut. Dengan kata lain, praktik (akuntansi) penjualan berupa tawar menawar merupakan aktivitas yang berhubungan dengan nilai kesabaran dan kegigihan yang bukan menjadi fokus utama dalam akuntansi modern. Namun yang menjadi pertanyaan adalah apakah kedua semangat akuntansi penjualan itu ditujukan hanya untuk mendapatkan keuntungan materi dan mengabaikan keadaan sekitar? Pertanyaan kemudian diajukan kepada pedagang terkait dengan itu:

"Mengapa setelah hari pasar, ta Meri memilih membagikan kue secara gratis? Apakah tidak memikirkan keuntungan akan berkurang ketika melakukan hal tersebut?"

ta Meri kemudian menjawab:

"Maksudnya yah amal saja itu, tidak usah diingat-ingat lagi keuntungannya. Yang penting. sudah ada yang akan dibelikan lagi pisang, beras, tepung. Biar untung sedikit-sedikit yang penting jualan kami itu, iya maksudnya untung biar hanya Rp100.000 lah. Lumayan, syukur alhamdulillah. Biar hanya sedikit-sedikit kan. Saya ini dari dulu berjualan, menyekolahkan anak-anak saya, uangnya dikumpul sedikit-sedikit dari keuntungan. Syukur alhamdulillah. Kali ini hanya begitu rejekinya". 
Cuplikan wawancara ta Meri tersebut secara tidak langsung dapat menjawab pertanyaan sebelumnya, bahwa semangat kegigihan dan kesabaran dalam memperoleh pendapatan penjualan tidak sebatas mencari keuntungan materi serta mengabaikan keadaan sekitar. Akan tertapi, terdapat niat untuk berbagi kepada sesama dan juga bersyukur kepada Tuhan. Hal itu tercermin dari tindakan ta Meri yang memberikan jualan beliau secara gratis kepada warga sekitar, padahal jualan tersebut masih layak untuk dijajakan kepada pembeli. Setelah dikonfirmsi, ta Meri dengan tegas mengungkapkan keinginan beliau untuk berbagi diantara sesama. Sementara itu, ta Meri tidak memikirkan lagi tentang besar kecilnya keuntungan dan lebih memilih untuk mensyukuri rejeki yang telah diberikan oleh Tuhan. Dengan demikian dapat dipahami nilai kesabaran dan kegigihan dari praktik akuntansi penjualan adalah semangat yang hidup beriringan dengan rasa saling berbagi serta syukur kepada Tuhan. Lebih lanjut, kedua nilai yang hidup pada praktik akuntansi penjualan merupakan refleksi dari nasihat para orang tua "mopo'o tanggalo duhelo" yang bermakna penuh kesabaran. "Lumadu mopo'o tanggalo duhelo" (membuka lebar dada) merupakan ungkapan yang syarat dengan pesan moral berupa melapangkan dada dalam menjalani kehidupan. Segala permasalahan bisa dihadapi dengan kesabaran dan kegigihan jika tidak mempersempit hati yang diberikan oleh Tuhan (Daulima \& Eraku, 2009). Ketidakputusasaan para pedagang dalam mencari rejeki yang halal serta sikap ramah kepada pembeli yang melakukan kompromi terhadap harga barang merupakan cerminan dari kedua nilai budaya Islam tersebut. Hal tersebut berarti nilai-nilai kearifan lokal Gorontalo ikut membentuk praktik akuntansi penjualan di pasar tradisional.

Sementara itu, akuntansi yang berhubungan dengan nilai-nilai kearifan lokal juga telah berhasil ditemukan dalam penelitian ini. Musdalifa \& Mulawarman (2019) dalam studi praktik akuntansi pendapatan berbasis budaya sibaliparriq (kerja sama) menemukan nilai kesabaran dan kegigihan sebagai semangat para anggota keluarga nelayan dalam mencari rejeki. Kedua semangat tercermin lewat beberapa kondisi, diantaranya adalah keteguhan hati para nelayan untuk tetap mencari rejeki meskipun harus meninggalkan keluarga selama berbulan-bulan. Terdapat kegigihan hati untuk terus melaut walaupun membawa pulang hasil yang tidak menentu atau mungkin hutang pada para punggawa (pemilik kapal), serta ketetapan hati untuk tetap menggantungkan kehidupan keluarga dari hasil laut sekalipun keselamatan menjadi taruhannya. Lebih lanjut, semangat kesabaran juga terdapat pada tindakan para istri nelayan ketika mempraktikkan akuntansi pendapatan. Tindakan tersebut berupa ikut bekerja keras sehingga dapat membantu perekonomian keluarga. Upah dari hasil pekerjaan memang tidak sebesar penghasilan suami, tetapi para istri menjalani hidup dengan rasa bahagia karena kebutuhan keluarga sudah terpenuhi. Kegiatan kerjasama dalam memenuhi kebutuhan keluarga merupakan implementasi dari nilai sibaliparing dalam masyarakat Mandar. Hal ini sesuai dengan akuntansi yang dipraktikkan oleh pengusaha bisnis besi tua. Nilai kesabaran dalam menjalankan usaha terefleksi lewat keputusan pengusaha besi tua untuk menerima penundaan pembayaran barang (tertundanya penerimaan pendapatan) yang dibeli secara borongan, serta tindakan pengusaha untuk terus melakukan aktivitas bisnis dan mencari barang dagangan meskipun pada saat itu usaha bisnis besi tua mengalami kerugian. Sikap pantang menyerah, selalu bekerja keras, dan menjaga kekompakan merupakan ciri khas masyarakat Madura yang mungkin terlihat sangat arogan dan keras, namun sebenarnya merupakan sebuah ketegasan bersikap apa adanya (Nurhalimah, Setiawan, dan Haryadi, 2019).

Selanjutnya, semangat kesabaran dan kegigihan dalam mencari rejeki yang halal pada hakikatnya seirama dengan apa yang diperintahkan oleh-Nya. Hal ini terlihat melalui salah satu "informasi wahyu" yang menyebutkan bahwa "Dan sungguh Kami benar-benar akan menguji kalian, sehingga Kami mengetahui orang-orang yang bersungguh-sungguh dalam agama Allah dan orangorang yang bersabar di antara kalian (Q.S Muhammad: 31)". Tuhan menciptakan manusia beserta dengan ujian kehidupan. Tujuan penciptaan ujian tersebut adalah untuk melihat siapa manusia yang bisa bersabar serta bersungguh-sungguh taat dalam ajaran agama Allah. Begitu pula dalam konteks penelitian ini, tawar menawar dipandang sebagai salah satu ujian yang diberikan oleh Tuhan kepada para pedagang di pasar tradisional. Ujian tersebut ditujukan untuk melihat kesabaran dan keteguhan hati mereka dalam mencari rejeki yang berkah dari Tuhan (ihsan). Ringkasan dari temuan penelitian ini telah diringkas pada Tabel 1 .

Kolom Amal berisi tentang amal atau cara pedagang di pasar tradisional dalam mempraktikkan akuntansi penjualan. Berdasarkan hasil kajian, ditemukan cara memperoleh pendapatan penjualan melalui proses tawar menawar. Proses tersebut terdapat pada amal "ditambah ya, dibuat panas itu timbangannya" dan "kalau perempuan yang berbelanja, kalau laki-laki paling kalau sudah ditimbangan kasian, sudah tidak lagi berkomentar". Pada kolom kedua (Ilmu) berisi tentang ilmu atau makna dari amal. Secara garis besar, makna yang ditemukan adalah "para pembeli dapat melakukan kompromi harga barang yang dijual oleh para pedagang". Pada kolom ketiga (Iman), terdapat iman berupa 
Thalib, Rahman, Abdullah, Gobel - Akuntansi potali: membangun...|31

Tabel 1. Ringkasan Analisis Temuan 1

\begin{tabular}{|c|c|c|c|c|}
\hline Amal & Ilmu & Iman & IW & Ihsan \\
\hline $\begin{array}{l}\text { "ditambah ya, } \\
\text { dibuat panas itu } \\
\text { timbangannya" }\end{array}$ & $\begin{array}{l}\text { para pembeli dapat melakukan kom- } \\
\text { promi harga barang yang dijual oleh } \\
\text { pedagang. }\end{array}$ & $\begin{array}{l}\text { kesabaran dan } \\
\text { kegigihan }\end{array}$ & $\begin{array}{l}\text { Q.S Muham- } \\
\text { mad: } 31\end{array}$ & $\begin{array}{l}\text { kesabaran dan } \\
\text { keteguhan hati } \\
\text { para pedagang }\end{array}$ \\
\hline $\begin{array}{l}\text { "kalau perempuan } \\
\text { yang berbelanja, } \\
\text { kalau laki-laki } \\
\text { paling kalau sudah } \\
\text { ditimbangan } \\
\text { kasian, sudah tidak } \\
\text { lagi berkomentar" }\end{array}$ & $\begin{array}{l}\text { pembeli laki-laki tidak melakukan kom- } \\
\text { promi harga barang dengan penjual. } \\
\text { Ketika penjual telah memberikan jumlah } \\
\text { barang sebagaimana yang mereka } \\
\text { beli, maka pembeli tidak akan melaku- } \\
\text { kan penawaran lagi. Berbeda dengan } \\
\text { pembeli perempuan, meskipun penjual } \\
\text { telah memberikan jumlah barang sesuai } \\
\text { dengan apa yang dibeli, namun pembeli } \\
\text { perempuan biasanya tetap meminta } \\
\text { agar penjual melebihkan jumlah barang } \\
\text { tersebut. }\end{array}$ & & & $\begin{array}{l}\text { dalam mencari } \\
\text { rejeki yang } \\
\text { berkah dari- } \\
\text { Nya }\end{array}$ \\
\hline
\end{tabular}

nilai kearifan lokal yang menggerakkan praktik akuntansi penjualan. Nilai itu berupa kesabaran dan kegigihan. Semangat ini merupakan cerminan dari lumadu "mopo'o tanggalo duhelo". Sementara itu, pada kolom keempat memuat tentang informasi wahyu yang seirama dengan nilai dari praktik akuntansi penjualan yang menyebutkan "Dan sungguh Kami benar-benar akan menguji kalian, sehingga Kami mengetahui orang-orang yang bersungguh-sungguh dalam agama Allah dan orangorang yang bersabar diantara kalian (Q.S Muhammad: 31)". Kolom kelima (Ihsan) berisi tentang pelajaran yang bisa diambil dari adanya praktik tawar menawar dalam memperoleh pendapatan penjualan. Hikmah tersebut adalah kesabaran dan keteguhan hati para pedagang dalam mencari rejeki yang berkah dari Tuhan.

\section{Bonus Kue dan Nilai Persaudaraan}

Pelanggan merupakan salah satu bagian terpenting dalam berdagang, bahkan ta Tini yang telah berjualan sekitar lima belas tahun mengungkapkan bahwa "mo bajual itu sanang kalau so ada pelanggan, biar bagimana tetap torang yang dorang mo cari" (berjualan itu senang kalau sudah ada pelanggan, biar keadaan bagaimana tetap kami yang dicari). Salah satu cara yang dilakukan oleh para penjual untuk mendapatkan pelanggan adalah dengan memberikan bonus kue kepada pembeli.

"Iya jelas tetap akan ditambah, orang yang membeli adakalanya ditambah satu, membeli lima ribu jadi enam. Karena mencari langganan, para penjual kue seperti itu, tetap saja tidak ada normalnya (kue) dijual seribu-seribu (dan hanya sejumlah dibeli itu yang dikasih, pasti diberikan tambahan). Iya orang-orang itu kan, bukan cuman (di tempat jualan) kami yang akan dibeli, rata-rata sekarang orang sudah berjualan. Sekarang ini di jalan-jalan sudah ada yang berjualan, jadi sudah tidak susah sekarang, kue-kue sudah ada, sedangkan kue-kue di dekat BRI kan dulunya tidak ada kue di sana, sekarang sudah ada kue, pokoknya sekarang ini tinggal uang yang akan ditanya".

Penjelasan ta Meri sebelumnya memberikan informasi tentang kebiasaan yang dilakukan oleh para penjual kue. Kebiasaan itu adalah memberikan tambahan kue kepada para pembeli. Hal ini dimaksudkan agar para pembeli merasa senang dan berkenan berkunjung lagi untuk melakukan pembelian. Sementara itu, ta Meri menjelaskan bahwa sekarang jumlah para pedagang kue semakin banyak dimana pembeli dapat membeli kue yang dijual di depan rumah pembeli tanpa harus menunggu hari pasar. Hal ini dirasakan pula oleh ta Nou.

“Keadaan sekarang kan, kalau mau mengeluh tidak juga karena berjualan tahun 80an sampai 90an tidak seperti sekarang ini. Sekarang di mana-mana terdapat warung, walau hanya di teras rumah. Coba kamu perhatikan sudah ada tempat jualan nasi kuning walau hanya disediakan di meja kecil. Kalau dulu tidak ada seperti itu. Coba kamu perhatikan jalan Bengawan Solo, Tanggida'a, Tanggikiki. Jalan-jalan itu sudah seperti pasar, kalau keadaan seperti dulu saya senang mencari kasihan".

Penuturan ta Nou sebelumnya memberikan pemahaman tentang perbedaan kondisi penjual di tahun 90an dan sekarang. Di era tahun 90an, para penjual hanya menjajakan dagangan di hari pasar. Oleh sebab itu, jumlah penjualan sedikit karena ruang untuk berjualan di pasar tradisional terbatas. Kondisi tersebut berbeda dengan kondisi sekarang dimana jumlah penjual kue semakin banyak. Hal ini disebabkan para penjual tidak menunggu hari pasar dan kemudian berjualan di tempat tersebut. Penjual sekarang menjajakan jualan di depan rumah masing-masing. Ta nou menjelaskan juga bahwa 
keadaan tersebut mempengaruhi pendapatan penjualan dan kelanjutan dari usaha. Oleh sebab itu, salah satu cara yang beliau lakukan agar bisa terus mendapatkan pendapatan adalah memberikan bonus kepada para pembeli. Hal ini dimaksudkan agar pembeli merasa senang dan berkenan melakukan pembelian lagi. Lebih lanjut, berdasarkan cuplikan wawancara ta Meri sebelumnya, peneliti menemukan praktik akuntansi penjualan berupa memberikan bonus. Praktik ini terdapat pada amal "jelas akan ditambah,... membeli lima ribu jadi enam". Ilmu dari amal ini adalah para penjual akan menambah kue kepada para pembeli. Harga kue perbiji adalah seribu, jika pembeli membeli dengan harga Rp5.000 maka jumlah yang akan didapatkan adalah 6 biji kue. Keputusan untuk memberikan tambahan kue dilakukan untuk menjaga kelangsungan usaha penjual. Lebih lanjut, hasil wawancara juga menemukan cara praktik akuntansi penjual berupa pemberian bonus. Praktik ini terdapat pada amal "bukan cuman di tempat jualan kami yang akan dibeli". Ilmu dari amal ini adalah para pembeli memiliki banyak pilihan tempat untuk membeli kue. Oleh sebab itu, pemberian bonus kue merupakan salah satu cara yang dilakukan oleh penjual kue agar bisa menarik hati pembeli. Pemberian bonus kue sebenarnya tidak saja diberikan atas inisiatif dari penjual, namun terkadang juga pembeli dengan sendirinya meminta untuk diberikan tambahan bonus kue, hal ini sebagaimana yang dialami oleh ta Tini ketika berjualan.

“Kalau orang membeli kue di tempat saya, misalnya membeli kue Rp 2.000, meminta untuk ditambah satu, terus saya katakan iya, silahkan diambil saja. Pokoknya dengan saya tidak ada pantangan apa”.

Penuturan ta Tini sebelumnya menunjukkan bahwa sebagai penjual ingin memberikan rasa nyaman kepada pembeli. Oleh sebab itu, apabila pembeli meminta untuk diberikan tambahan kue, maka ta Tini akan memberikannya. Penuturan ta Tini tersebut sekaligus berarti bahwa tidak saja penjual yang dengan sendirinya memberikan bonus kue kepada pembeli, namun terdapat juga pembeli yang meminta secara langsung kepada penjual. Hasil wawancara dengan ta Tini juga ditemukan praktik akuntansi penjulan berupa pemberian bonus. Praktik ini terekam pada amal "meminta untuk ditambah satu". Ilmu dari amal ini adalah ketika pembeli ingin mendapatkan tambahan kue, maka pembeli bisa meminta langsung. Penjual memberikan bonus kue sebagaimana permintaan pembeli karena penjual ingin pembeli merasa nyaman. Hal tersebut sama dengan apa yang dilakukan oleh kedua informan sebelumnya, ta Nou juga mempraktikkan akuntansi penjualan yang sama.

"Begitu juga kalau berjualan kue, saya menjualnya seribu per biji. Saya pikir kalau kuenya tersisa kemudian saya bawa pulang ke rumah, nanti tidak ada yang makan. Saya akan tambah kuenya, mereka membeli sepuluh biji, saya tambah satu (kue), kalau mereka hanya membeli lima ribu, tetap saya tambah satu. Artinya dari keikhlasan saya, agar langganan saya maju. "ah saya akan membeli saja di sana kuenya sering ditambah". Artinya saya gunakan untuk memancing pelanggan, biar kalian liat saya ini orang susah, tapi saya tidak ingin hati saya sekeras batu. Artinya saya pikir, di kue satu biji itu, saya tidak akan ditegur di jalan".

Pada penuturan ta Nou sebelumnya, dapat diketahui bahwa terdapat 3 alasan pemberian tambahan kue Alasan pertama untuk menghindari kerugian. Alasan kedua adalah untuk menarik minat konsumen agar melakukan pembelian lagi. Ta Nou berharap dengan memberikan bonus kue kepada pembeli dapat membuat hidup bahagia kemudian pembeli berkenan melakukan pembelian lagi. Alasan ketiga yaitu untuk menjaga hubungan baik antara pembeli dan penjual. Para pembeli yang berbelanja di pasar kamis mayoritas merupakan warga sekitar, sehingga upaya pemberian bonus kue sebenarnya merupakan salah satu cara yang digunakan oleh ta Nou untuk menjaga dan menjalin silaturahmi dengan pembeli. Hasil wawancara tersebut menunjukkan praktik akuntansi penjualan berupa memberikan bonus. Praktik ini terdapat pada amal "membeli sepuluh biji, saya tambah satu kue, kalau mereka hanya membeli lima ribu, tetap saya tambah satu". Amal ini memiliki makna (ilmu) ketika ada pembeli membeli kue sejumlah 5 biji, maka penjual akan memberikan lebih dari jumlah tersebut. Dengan kata lain, jumlah kue yang didapatkan oleh pembeli melebihi dari jumlah harga yang diberikan. Upaya penambahan kue merupakan hal yang pasti meskipun patokan pemberian tambahan kue serta jumlah kue yang akan ditambahkan tidak pasti (sesuai keikhlasan). Masih pada cuplikan wawancara yang sama, ditemukan praktik akuntansi penjualan berupa pemberian bonus. Praktik ini terdapat pada amal "memancing pelanggan". Ilmu dari amal ini adalah penjual memberikan tambahan kue kepada pembeli adalah untuk mempertahankan kelanjutan usaha.

Tindakan memberikan tambahan kue yang dilakukan oleh ta Nou juga menjadi perhatian utama dalam penelitian ini. Ta Nou selalu menambahkan jumlah kue dari total yang dibeli. Terdapat suasana yang penuh keakraban antara penjual dengan para pembeli. Kalimat-kalimat bercanda sering diteriakkan oleh penjual untuk menarik minat pembeli "laris manis, laris manis". Perhatian 
peneliti selanjutnya tertuju pada tindakan ta Nou yang mencoba tidak menambahkan jumlah kue pada salah seorang pembeli dengan candaan pembeli "ih bo tidak tamba? (kuenya tidak ditambah?)" ta Nou pun langsung menjawab "iyo langgamo mo tamba (iya, nanti ditambah)". Kejadian tersebut sebenarnya merupakan isyarat bahwa aktivitas menambah kue telah menjadi kegiatan yang terus berulang serta telah membangun pemahaman rasional bersama (ilmu). Pemahaman yang tidak perlu diungkapkan lagi oleh setiap anggota kelompok. Pemahaman bersama itu adalah jumlah kue yang didapatkan atau diberikan melebihi jumlah harga yang dibayarkan. Apabila tindakan berulang ini tidak dilakukan maka akan timbul keanehan (terganggunya tatanan sosial) diantara sesama anggota. Salah satu reaksi dari ketidakteraturan tersebut adalah menanyakan kenapa tindakan yang telah biasa terjadi atau berulang (pemberian tambahan bonus kue) tidak dilakukan. Hal ini sebagaimana dengan yang dilakukan oleh salah satu pelanggan dari ta Nou.

Dengan demikian dapat dipahami bahwa jika kue yang dijual perbiji adalah Rp1.000 dan pembeli membeli dengan harga Rp5.000, sehingga total yang didapatkan adalah lima biji kue. Aktivitas jual beli tersebut pada umumnya merupakan hal yang wajar. Hal ini disebabkan jumlah yang dibeli sama dengan jumlah yang didapatkan. Namun dalam konteks ruang dan waktu yang berbeda di pasar Kamis, kejadian tersebut (harga kue Rp1.000 membeli harga Rp5.000 mendapatkan 5 buah kue) menjadi aktiviitas yang tidak wajar. Kondisi tersebut disebabkan karena tindakan menambah kue telah menjadi aktivitas "berulang/biasa" yang sudah membentuk pemahaman bersama (yang tidak perlu dijelaskan) oleh ta Nou dan pelanggan. Pemahaman bersama itu adalah jumlah kue yang didapatkan atau diberikan melebihi jumlah harga yang dibayarkan. Selanjutnya, berdasarkan pembahasan sebelumnya, dapat diketahui bahwa terdapat harapan dari para penjual ketika memberikan tambahan kue tersebut. Harapan penjual adalah agar kelangsungan usaha bisa dipertahankan di tengah persaingan yang ada. Harapan tersebut tidak hanya berkaitan dengan upaya mendapatkan uang tapi juga untuk menjalin hubungan kekeluargaan di antara sesama. Hal ini sebagaimana yang telah diungkapkan oleh pedagang yang ingin pembeli merasa senang dan nyaman bertransaksi dengan para penjual yang merasa tidak enak hati ketika tidak memberikan tambahan kue kepada pembeli. Sementara itu, hasil dari semangat menjalin hubungan kekeluargaan ini terlihat lewat keakraban antara pembeli dan penjual ketika bertransaksi. Pembeli dengan santai meminta tambahan kue kepada penjual, penjual yang terkadang mengerjai pembeli dengan cara tidak menambahkan kue, merupakan sedikit cerminan keakraban yang terekam dalam penelitian ini. Kondisi tersebut menunjukkan praktik akuntansi penjualan berupa memberikan bonus digerakkan dengan nilai non-materi (iman) berupa upaya untuk menjalin rasa kekeluargaan atau persaudaraan.

Semangat persaudaraan merupakan salah satu pesan moral yang sering ditanamkan oleh orang tua kepada masyarakat Gorontalo melalui lumadu (ungkapan) "dila bo mo tambanga o'ahu, bo motambanga nyawa (tidak hanya saling menindih sendok, hanya saling menindih nyawa)". Salah satu pesan moral dari ungkapan itu adalah hubungan kekeluargaan. Rasa persaudaraan yang dibangun berdasarkan pada harta perlahan akan menghilang seiring berkurangnya materi yang dimiliki. Oleh sebab itu, hubungan kekeluargaan dibangun berdasarkan ketulusan hati. Kekerabaran yang didasarkan pada ketulusan tidak akan pernah pudar sekalipun uang tidak lagi dimiliki (Daulima \& Eraku, 2009). Tindakan para pedagang yang memberikan bonus kue merupakan cerminan dari keinginan para penjual menjalin hubungan kekeluargaan di antara sesama. Dalam sudut akuntansi modern, hal tersebut dianggap sebatas strategi bisnis dalam mendapatkan keuntungan, menjaga keberlangsungan usaha yang pada hakikatnya berhubungan dengan nilai kepentingan pribadi. Namun, bagi para penjual di pasar tradisional, upaya untuk menjalin hubungan kekeluargaan merupakan salah satu hal yang diutamakan dalam aktivitas hidup (termasuk berjualan), sebagaimana yang disampaikan oleh ta Nou "biar kamu liat kita susa bagini, kita pe hati dengan orang tidak sekeras batu. Artinya kita pikir, dikue satu dua biji itu, tidak mo tegur kita di jalan (biar kalian liat saya ini orang susah, tapi saya tidak ingin hati saya sekeras batu.

Dengan demikian, dapat dipahami bahwa para pedagang di pasar tradisional mempraktikkan akuntansi penjualan dengan nilai budaya Islam Gorontalo. Semangat itu berupa hubungan kekeluargaan. Lebih lanjut, praktik akuntansi yang syarat dengan nilai kekeluargaan juga sebenarnya diimplementasikan oleh beberapa pengusaha lainnya. Misalnya juragan bubur yang sudah mengganggap karyawan sebagai anak sendiri. Perasaan tersebut hadir disebabkan niat mendirikan usaha adalah untuk beribadah kepada Tuhan. Oleh sebab itu, pemilik usaha merasa para pekerja tersebut merupakan amanah yang dititipkan oleh Tuhan untuk diperlakukan dengan adil dan bijaksana (Kusdewanti \& Hendrawaty, 2014). Hal ini sesuai dengan yang diimplementasikan oleh pengusaha kebun karet kepada tukang motong (pekerja). Nilai kekeluargaan tercermin lewat pembagian pendapatan (bagi hasil) lebih besar diberikan kepada tukang motong. Aktivitas tersebut terjadi karena keinginan masyarakat Kampar Riau khususnya pemilik kebun untuk membantu meringankan beban 
Tabel 2. Ringkasan Temuan 2

\begin{tabular}{|c|c|c|c|c|}
\hline Amal & Ilmu & Iman & IW & Ihsan \\
\hline $\begin{array}{l}\text { "jelas tetap akan } \\
\text { ditambah,... membeli } \\
5.000 \text { jadi } 6 "\end{array}$ & $\begin{array}{l}\text { para penjual akan menambah kue } \\
\text { kepada para pembeli. Harga kue } \\
\text { perbijinya adalah seribu, jika pembeli } \\
\text { membeli dengan harga Rp } 5.000 \text { maka } \\
\text { jumlah yang akan didapatkan pembeli } \\
\text { adalah } 6 \text { biji kue. }\end{array}$ & \multirow[t]{5}{*}{ persaudaraan } & $\begin{array}{l}\text { (HR } \\
\text { Bukhori- } \\
\text { Muslim)". } \\
\text { (Q.S. Ar- } \\
\text { Rum Ayat } \\
\text { 37)” }\end{array}$ & \multirow{5}{*}{$\begin{array}{l}\text { kelapangan dan } \\
\text { kesempitan rejeki } \\
\text { merupakan hak dan } \\
\text { ketetapan-Nya. Oleh } \\
\text { sebab itu, dalam } \\
\text { mencari pendapa- } \\
\text { tan, hal yang harus } \\
\text { diutamakan adalah } \\
\text { keberkahannya. }\end{array}$} \\
\hline $\begin{array}{l}\text { "bukan cuman di tem- } \\
\text { pat jualan kami yang } \\
\text { akan dibeli" }\end{array}$ & $\begin{array}{l}\text { para pembeli kue memiliki banyak } \\
\text { pilihan tempat untuk membeli kue. } \\
\text { Oleh sebab itu, memberikan bonus kue } \\
\text { merupakan salah satu cara yang dilaku- } \\
\text { kan oleh penjual kue agar bisa menarik } \\
\text { hati pembeli. }\end{array}$ & & & \\
\hline $\begin{array}{l}\text { "meminta untuk dit- } \\
\text { ambah satu" }\end{array}$ & $\begin{array}{l}\text { ketika pembeli ingin mendapatkan tam- } \\
\text { bahan kue, maka mereka bisa memin- } \\
\text { tanya langsung. }\end{array}$ & & & \\
\hline $\begin{array}{l}\text { "membeli sepuluh biji, } \\
\text { saya tambah satu kue, } \\
\text { kalau mereka hanya } \\
\text { membeli } 5.000 \text {, tetap } \\
\text { saya tambah satu" }\end{array}$ & $\begin{array}{l}\text { ketika ada pembeli membeli kue } \\
\text { sejumlah lima biji, maka penjual akan } \\
\text { memberikan lebih dari jumlah tersebut. }\end{array}$ & & & \\
\hline $\begin{array}{l}\text { "memancing pelang- } \\
\text { gan" }\end{array}$ & $\begin{array}{l}\text { Penjual memberikan tambahan kue } \\
\text { kepada pembeli adalah untuk memper- } \\
\text { tahankan kelanjutan usaha. }\end{array}$ & & & \\
\hline
\end{tabular}

ekonomi dari pekerja. Semangat kekeluargaan (solidaritas) yang dimiliki oleh masyarakat setempat tidak terlepas dari nilai-nilai ajaran agama Islam. Nilai tersebut terdapat pada filosofi "adat bersendi syara, syara bersendi kitabullah, apa yang terdapat dalam agama Islam, itu yang dipakai oleh adat" (Harkaneri et al., 2014).

Lebih lanjut, nilai kekeluargaan yang menjadi semangat para pedagang mempraktikkan akuntansi penjualan merupakan salah satu nilai yang diperintahkan oleh-Nya. Hal tersebut terlihat lewat "informasi wahyu" yang menyebutkan bahwa:

"Barangsiapa yang ingin dilapangkan rezekinya dan dipanjangkan umurnya maka hubungkan silaturahmi" (HR Bukhori-Muslim). "Dan apakah mereka tidak memperhatikan bahwa Sesungguhnya Allah melapangkan rezeki bagi siapa yang dikehendaki-Nya dan Dia (pula) yang menyempitkan (rezeki itu). Sesungguhnya pada yang demikian itu benarbenar terdapat tanda-tanda (kekuasaan Allah) bagi kaum yang beriman" (Q.S. Ar-Rum Ayat 37.)

Tindakan para penjual berupa pemberian tambahan kue, terciptanya keakraban ketika bertransaksi, hingga bertahannya usaha dalam persaingan yang tinggi merupakan gambaran perjalanan hidup para pedagang dalam memperoleh pendapatan penjualan. Cerita kehidupan tersebut diciptakan oleh Tuhan untuk mengingatkan manusia bahwa pada hakikatnya kelapangan dan kesempitan rejeki merupakan hak dan ketetapan dari Tuhan yang merupakan Sang Maha Melapangkan dan Menyempitkan Rejeki (ihsan). Oleh sebab itu, hal yang diutamakan dalam memperoleh pedapatan adalah keberkahan dari Tuhan.

Tabel 2 tersebut merupakan ringkasan temuan kedua dari penelusuran praktik akuntansi penjualan di pasar tradisional Gorontalo. Pada kolom pertama terdapat amal. Hasil penelitian menemukan bahwa pendapatan penjualan diperoleh oleh penjual melalui pemberian bonus kue kepada pembeli. Hal tersebut terdapat pada amal "jelas tetap akan ditambah, membeli 5.000 jadi 6", "bukan cuman di tempat jualan kami yang akan dibeli", "meminta untuk ditambah satu", "membeli sepuluh biji, saya tambah satu kue, kalau mereka hanya membeli 5.000”, tetap saya tambah satu”, "memancing pelanggan". Pada kolom kedua, terdapat ilmu (makna rasional dari amal). Secara garis besar, dapat dipahami bahwa makna tersebut berupa "jumlah kue yang diberikan oleh penjual melebih nominal harga yang dibayar oleh pembeli". Sementara itu, pada kolom ketiga berisi tentang temuan nilai persaudaraan yang tersirat pada lumadu (ungkapan) "dila bo mo tambanga o'ahu, bo motambanga nyawa". Lebih lanjut, kolom keempat berisi temuan tentang informasi wahyu berupa:

"Barangsiapa yang ingin dilapangkan rezekinya dan dipanjangkan umurnya maka hubungkan silaturahmi" (HR Bukhori-Muslim). "Dan apakah mereka tidak memperhatikan bahwa Sesungguhnya Allah melapangkan rezeki bagi siapa yang dikehendaki-Nya dan Dia (pula) yang menyempitkan (rezeki itu). Sesungguhnya pada yang demikian itu benar- 


\section{benar terdapat tanda-tanda (kekuasaan Allah) bagi kaum yang beriman" (Q.S. Ar-Rum}

Ayat 37).

Kolom terakhir (kelima) memuat tentang hikmah yang dapat diambil dari praktik akuntansi penjualan. Hikmah tersebut berupa kelapangan dan kesempitan rejeki merupakan hak dan ketetapan dari Tuhan. Oleh sebab itu, dalam mencari pendapatan, maka hal yang harus diutamakan adalah keberkahan dari Tuhan.

Berdasarkan pembahasan sebelumnya, maka penelitian ini mengonstruksi cara pedagang di pasar tradisional Gorontalo dalam mempraktikkan akuntansi penjualan. Rumusan dari temuan tersebut tersaji pada Gambar 1. Sebagaimana yang ditampilkan pada gambar tersebut, terdapat amiiin sebagai alat yang digunakan oleh peneliti dalam membangun temuan penelitian. Tahapan pertama adalah amal dimana analisis data ini menghasilan dua cara pedagang mempraktikkan akuntansi penjualan yaitu; melakukan tawar menawar dan memberikan bonus kue. Tahapan kedua adalah ilmu dimana analisis ini menemukan bahwa praktik tawar menawar memiliki makna rasionalitas berupa pembeli dapat melakukan kompromi harga barang yang dijual oleh para pedagang. Selanjutnya, pemahaman bersama dari praktik akuntansi penjualan berupa memberikan bonus kue adalah jumlah kue yang diberikan oleh penjual melebihi jumlah harga yang dibayar oleh pembeli.

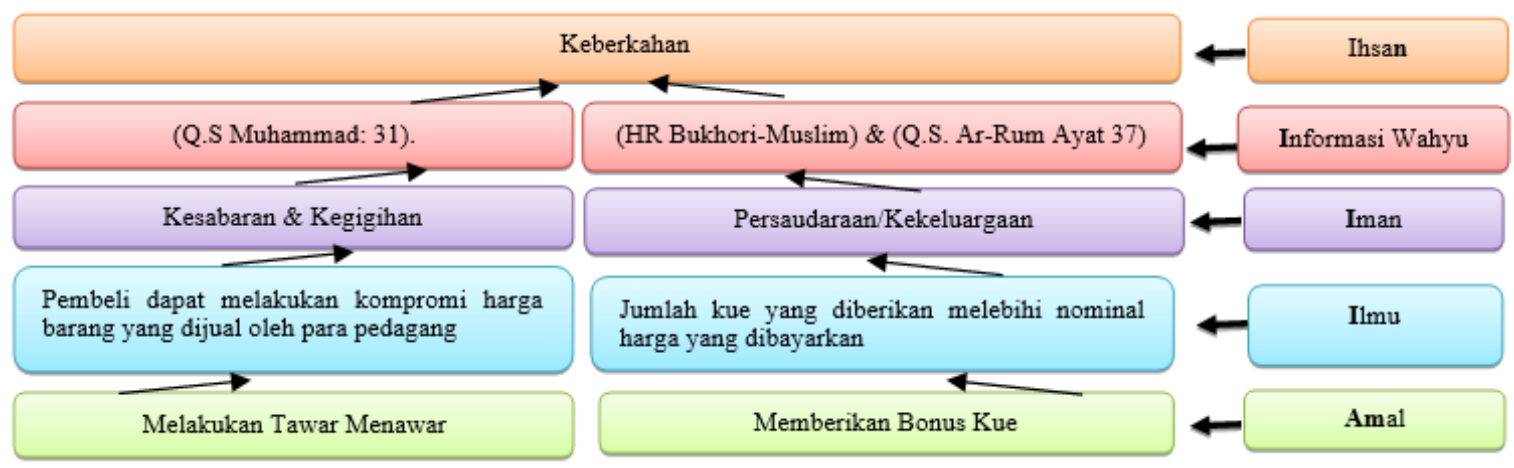

Gambar 1. Konstruksi Akuntansi Penjualan oleh Pedagang di Pasar Tradisional Gorontalo

Tahapan analisis ketiga adalah iman. Pada tahapan ini, ditemukan nilai-nilai non materi dan nilai budaya Islam Gorontalo yang menjadi semangat para penjual mempraktikkan akuntansi penjualan. Nilai yang pertama adalah kegigihan dan kesabaran. Nilai tersebut ditemukan menjadi semangat dari pedagang ketika mempraktikkan akuntansi penjulan berupa tawar menawar. Kesabaran dan kegiginan para penjual itu merupakan cerminan dari pengimplementasian lumadu "mopo'o tanggalo duhelo (membuka lebar dada)". Selanjutnya, berhubungan dengan nilai kekeluargaan yang merupakan semangat dari pedagang mempraktikkan akuntansi penjualan berupa memberikan bonus kue. Upaya untuk menjalin hubungan persaudaraan merupakan salah satu nasihat yang sering disampaikan oleh orang tua kepada masyarakat Gorontalo. Nasihat tersebut salah satunya tertuang dalam lumadu "dila bo mo tambanga o'ahu, bo motambanga nyawa (tidak hanya saling menindih sendok, hanya saling menindih nyawa)". Tahapan analisis data keempat adalah merelasikan nilai-nilai yang menjadi penggerak para penjual mempraktikkan akuntansi dengan informasi wahyu, dan ditemukan bahwa nilai kesabaran dan kegigihan seirama dengan perintah-Nya yang terdapat pada (Q.S Muhammad: 31). Selanjutnya, nilai kekeluargaan terdapat pada HR Bukhori-Muslim tentang menjalin hubungan tali silahturahmi dan Q.S. Ar-Rum Ayat 37. Tahapan analisis data kelima adalah ihsan. Tahapan ini berusaha untuk mengambil hikmah dari praktik akuntansi penjualan yang dilakukan oleh pedagang di pasar tradisional. Disamping itu, penelitian ini menemukan bahwa keberkahan rejeki merupakan hal yang diutamakan oleh para penjual. Keberkahan rejeki tersebut tercermin melalui keharmonisan hubungan dengan sesama, pendapatan yang sedikit namun cukup untuk menghidupi keluarga dan biaya pendidikan anak, serta hati yang bersyukur atas segala nikmat yang Tuhan berikan. Berdasarkan hal tersebut maka dapat diektahui bahwa akuntansi penjualan (potalia) yang ditemukan dalam penelitian ini adalah kegiatan mencari rejeki berbasis semangat kesabaran, kegigihan, dan kekeluargaan untuk meraih berkah dari Sang Ilahi.

\section{SIMPULAN DAN SARAN}

Penelitian ini bertujuan untuk merumuskan cara pedagang di pasar tradisional Gorontalo mempraktikkan akuntansi penjualan. Hasil penelitian menemukan bahwa dalam memperoleh pendapatan penjualan, para pedagang menggunakan dua cara yaitu tawar menawar dan memberikan bonus kue. Praktik akuntansi penjualan berupa tawar menawar digerakkan oleh nilai non materi yaitu 
kegigihan dan kesabaran. Kedua nilai tersebut merupakan cerminan dari pengimplementasian kearifan lokal berupa “mopo'o tanggalo duhelo (penuh kesabaran)". Selanjutnya, praktik akuntansi penjualan berupa memberikan bonus kue digerakkan oleh semangat kearifan lokal berupa persaudaraan. Spirit tersebut merupakan cerminan dari lumadu "dila bo mo tambanga o'ahu, bo motambanga nyawa (tidak hanya saling menindih sendok, hanya saling menindih nyawa)". Semangat berupa kesabaran, kegigihan, dan persaudaraan tersebut hadir disebabkan para pedagang ingin memperoleh rejeki yang berkah dari Tuhan. Keterbatasan penelitian ini adalah subjek penelitian dengan jenis dagangan gorengan dan kue. Berdasarkan temuan dan keterbatasan penelitian ini, maka saran untuk penelitian selanjutnya adalah untuk menelusuri dan menghadirkan praktik akuntansi (misalnya hutang, biaya, dan modal) di pasar tradisional yang berhubungan dengan nilai-nilai kearifan lokal pada pedagang dengan barang dagangan dan omset penjualan yang berbeda. Penelusuran tersebut tidak saja dapat memperkaya litelatur yang ada, namun juga sekaligus mempetahankan keberadaan akuntansi lokal dari banyaknya upaya pengadopsian akuntansi modern.

\section{DAFTAR RUJUKAN}

Burhan, B. (2012). Analisis Data Penelitian Kualitatif. Jakarta: PT. Rajagrifindo Perseda.

Creswell, W. J., Lazuardi, A. L., \& Qudsy, S. Z. (2015). Penelitian Kualitatif \& Desain Riset: Memilih Diantara Lima Pendekatan. Yogyakarta: Pustaka Pelajar.

Daulima, F., \& Eraku, S. (2009). Lumadu (Ungkapan) Sastra Lisan Daerah Gorontalo. Gorontalo: Galeri Budaya Dareah Mbu'i Bungale.

Garfinkel, H. (1967). Studies in ETHNOMETHODOLOGY. New Jersey: Polity.

Harkaneri, Triyuwono, I., \& Sukoharsono, E. G. (2014). Memahami Praktek Bagi-Hasil Kebun Karet Masyarakat Kampar Riau (Sebuah Studi Etnografi). Al-Istishad, 1(10), 14-38. doi:10.24014/jiq. v10i2.3115.

Ikatan Akuntan Indonesia. (2015). PSAK No. 23 Tentang Pendapatan. Dewan Standar Akuntansi Keuangan. Jakarta: PT. Raja Grafindo.

Kamayanti, A. (2015). Paradigma Penelitian Kualitatif dalam Riset Akuntansi: Dari Iman Menuju Praktik. Infestasi, 11(1), 1-10. doi:10.21107/infestasi.v11i1.1119.

Kamayanti, A. (2016a). Fobi(a)kuntansi: Puisisasi dan Refleksi Hakikat. Jurnal Akuntansi Multiparadigma, 7, 1-16. doi:10.18202/jamal.2016.04.7001.

Kamayanti, A. (2016b). Metodologi Penelitian Kualitatif Akuntansi Pengantar (Kedua). Surabaya: Yayasan Rumah Peneleh.

Kamayanti, A., \& Ahmar, N. (2019). Tracing Accounting in Javanese Tradition. International Journal of Religious and Cultural Studies, 1(1), 15-24. doi:10.34199/ijracs.2019.4.003.

Kuntowijoyo. (2007). Islam Sebagai Ilmu: Epistemologi, Metodologi, dan Etika. Yogyakarta: Tiara Wacana.

Kusdewanti, A. I., \& Hendrawaty, R. (2014). Memaknai Manajemen Bisnis Islami Sebagai Kehidupan yang Menghidupi. IMANENSI:Jurnal Ekonomi, Manajemen dan Akuntansi Islam, 1(2), 35-53. doi:10.34202/imanensi.2.1.2014.32-50

Mathews, M. R., \& Perera, M. H. B. (1993). Accounting Theory and Development. London: Thomson Publishing Company.

Moleong, L. J. (2015). Metodologi Penelitian Kualitatif. Bandung: PT. Remaja Roosdakarya.

Mulawarman, A. D. (2010). Integrasi Paradigma Akuntansi: Refleksi atas Pendekatan Sosiologi dalam Ilmu Akuntansi. Jurnal Akuntansi Multiparadigma, 1(1), 155-171. doi:10.18202/ jamal.2010.04.7086.

Mulawarman, A. D. (2013). Nyanyian Metodologi Ala Nataatmadja: Melampaui Derridian Mengembangkan Pemikiran Bangsa "Sendiri." Jurnal Akuntansi Multiparadigma, 4(1), 149 164. doi:10.18202/jamal.2013.04.7189.

Musdalifa, E., \& Mulawarman, A. D. (2019). Budaya Sibaliparriq dalam Praktik Household Accounting. Jurnal Akuntansi Multiparadigma, 10(3), 413-432. doi:10.21776/ub.jamal.2019.10.3.24. 
Nurhalimah, Setiawan, A. R., \& Haryadi, B. (2019). Praktik Akuntansi Manajemen Bisnis Besi Tua Berbasis Budaya Persaudaraan Madura. Jurnal Akuntansi Multiparadigma, 10(1), 1-21. doi:10.18202/jamal.2019.04.10001.

Purwanto, Y. (2007). Epistemologi Psikologi Islami: Dialektika Pendahuluan Psikologi Barat dan Psikologi Islami. Bandung: PT. Refika Aditama.

Sardar, Z. (1985). Masa Depan Islam. Bandung: Pustaka.

Sugiyono. (2014). Memahami Penelitian Kualitatif. Bandung: Alfabeta.

Thalib, M. A. (2017). Akuntansi “Cinta” Di Upacara Pernikahan Gorontalo, Studi Etnometodologi Islam. Thesis. Universitas Brawijaya.

Thalib, M. A. (2019a). Akuntansi "Huyula" (Konstruksi Akuntansi Konsinyasi Berbasis Kecerdasan Intelektual, Emosional, Spiritual, dan Sosial). Jurnal Riset Akuntansi doi:10.26486/jramb. v5i2.768.

Thalib, M. A. (2019b). Mohe Dusa: Konstruksi Akuntansi Kerugian. Jurnal Riset dan Aplikasi: Akuntansi Dan Manajemen, 4(1), 11-31. doi:10.18382.

Triyuwono, I. (2011a). "Sususaya” Melampaui Paradigma-Paradigma Metodologi Penelitian. Makalah. Accounting Research Training Series 2. Fakultas Ekonomi dan Bisnis. Universitas Brawijaya. 7-8 Desember 2011.

Triyuwono, I. (2011b). Angels Sistem Penilaian Tingkat Kesehatan Bank Syariah, 2(1), 1-21. Jurnal Akuntansi Multiparadigma. doi:10.18202/jamal.2011.04.7107.

Triyuwono, I. (2015). Akuntansi Malangan: Salam Satu Jiwa dan Konsep Kinerja Klub Sepak Bola. Jurnal Akuntansi Multiparadigma, 6(2), 290-303. doi:10.18202/jamal.2015.08.6023.

Triyuwono, I. (2013). (Makrifat) Metode Penelitian Kualitatif (dan Kuantitatif) untuk Pengembangan Disiplin Akuntansi. Simposium Nasional Akuntansi, September, 1-15.

Wiyarni, Triyuwono, I., Ludigdo, U., \& Djamhuri, A. (2013). Javanese Traditional Market Cultural Value in Accounting World. IOSR Journal of Business and Management, 10(5), 9-16. doi:10.9790/487X-1050916. 
Halaman ini sengaja dibiarkan kosong 